\title{
Effect of Weed Management on Insect Pest Population on Cotton (Gossypium Hirsutum L.) At Werer, Ethiopia
}

\author{
Workishet Taye* \\ Ethiopian Institute of Agricultural Research, Melkassa Agricultural Research Center P. O. Box 2003, Addis \\ Ababa, Ethiopia.
}

*Corresponding Authors: Workishet Taye, Ethiopian Institute of Agricultural Research, Melkassa Agricultural Research Center P. O. Box 2003, Addis Ababa, Ethiopia.

\begin{abstract}
Weeds are important hosts of insect pests and pathogens in agroecosystems. Presence of weeds can enhance or hinder arthropod fitness within the crop field. Weeds could influence the attractiveness of insect pests by the reflectance pattern of a site light, color and odor of the foliage. Therefore, to determine effect of weeding frequency on insect pest population a field experiment was conducted at Werer Agricultural Research Center during the main cropping season of 2016. A total of twenty-four treatments (Weedy check, one hand weeding at 20 DACE, two hand weeding at 34 DACE and three hand weeding at 48 DACE) in two sets (Open and controlled field) were laid out in a Randomized Complete Block Design with three replications. Then 21 days after emergence of cotton crop, insects in appeared on the crop and weed were collected and identified. Similarly, weeds in in both fields were sampled and identified., A total of 14 insect species, belonging to 13 families, and one spider were recorded from the experimental fields. About 50 percent of the insect species were from order Hemiptera. In both open and controlled field, weedy check has the highest insect population which accounting for $33.7 \%$ and $28.1 \%$ of insect species for open and controlled field, respectively. Insect pests were recorded from four weed species belonging to four families (Solanaceae, Tiliaceae, Aizoaceae and Amaranthaceae). The insect pest encountered in this study appeared in two categories in relation to the weed situation in the cotton crop. As weeding regime increases in the cotton field diversity of insect pests' decreases and the population of polyphagous insects (Aphis gossypii and Thrips tabaci) increases.
\end{abstract}

Keywords: Frequency, insect pest and weeds

\section{INTRODUCTION}

Weeds are important hosts of insect pests and pathogens in agroecosystems. Van Emden and Dabrowski (1997) cites 442 references relating to weeds as reservoirs of pests. More than seventy families of arthropods affecting crops were reported as being primarily weeds associated (Bendixen and Horn, 1981). Many pest outbreaks can be traced to locally abundant weeds belonging to the same family as the affected crop plants. Many insect pests are sufficiently polyphagous and thus, weeds unrelated to the crop may also be pest reservoirs. For example, Aphis gossypii feeds on over twenty unrelated weed species within and around cotton fields. Weedy plants near crop fields can provide requisites for pest outbreaks. Gliessman (2001) reported that weed borders are used in an agroecosystem to attract insects, facilitating colonization in the adjacent cauliflower crop.

Presence of weeds within-crop field modifies microclimate (Edwards and Wratten, 1980; Ochoa et.al., 1999). For example, changes in canopy parameters influenced by the presence of weeds can enhance or hinder arthropod fitness within the crop field. Nyambo (1988) reported that in Tanzania, Cleome sp. was an alternative host for the bollworm (Helicoverpa armigera) and assisted in the biological control of the pest in two ways; firstly, by providing a source of insects which were not pesticide resistant, having escaped the spray applied to the cotton crop and also in supporting a more diverse parasitoid population. It was confirmed that parasitism of $H$. armigera was greater on the weed than on cotton (Nyambo, 1990). In Sudan, eradication of Abutilon spp. and Solanum dubium L. is encouraged by legislation as part of the management programme for cotton pests. Malvaceous shrubs are often preferred over cotton as a food source for Earias spp. and they migrate to nearby cotton crops only in drier areas where natural vegetation is sparse (Hillocks, 1998). 
Numerous weeds support actively feeding and reproducing two spotted spider mites (Tetrany chusurticae), which dispersed to adjacent cotton crops as the weeds senesced in the spring (Wilson, 1995); management of the weeds was considered to potentially reduce mite infestation on the cotton seedlings (Reference).

Kennedy, (1993) had reported that insects are attracted to short-wave length ultraviolet light, during the dispersal phase and this tended to take insects upward toward the sky. After a period of flight, they become not attracted to ultraviolet light, instead preferring long-wavelength (often heat emanating from the soil or plants) light. Vegetation (weeds vs. bare soil, or weeds plus crop plants vs. crops plus bare soil) could influence the spectral reflectance pattern of a site, there by affecting the propensity of flying insects towards light (Capinera 2005). Weeds can also modify the attractiveness of insects to crops by affecting the hue (color) of the foliage; as first demonstrated conclusively by Kennedy, (1993), many herbivorous insects are attracted to yellow or yellowish green during the host-seeking phase, relative to dark green or other colors (Kostal and Finch, 1996). In many cases, insects using odor for host location tend to be more selective in their feeding habits than insects depending mostly on vision (Capinera, 2005).

The presence of weeds within or around crop fields influences the dynamics of the crop and associated biotic communities.? Many studies had produced a number of evidence that manipulation of a specific weed species, a particular weed-control practice, or a cropping system can affect the ecology of insect pests and associated natural enemies (Thresh, 1981; William, 1981; Norris, 1982; Andow, 1983). Therefore, the present study was mainly designed to assess the effect of weeding frequency on the insect pest's population in cotton field.

\section{Material AND Methods}

The experiment was conducted at Werer Agricultural Research Center (WARC) during the main cropping season from May to October, 2016. The center is located at $278 \mathrm{~km}$ east of Addis Ababa with an altitude of 740 meters above sea level and at the coordinates of $90^{\circ} 60^{\prime} \mathrm{N}$ and $40^{\circ} 09^{\prime} \mathrm{E}$. 1 . The dominant soil type of the experimental field of the center is described as chromic vertisol, Sand $3.83 \%$, Silt $61.1 \%$, and clay $35.07 \%$ having a bulk density of 1.17 . The $\mathrm{pH}$ of the soil ranges from 7.5 to 8.5 . The mean annual rainfall is $540 \mathrm{~mm}$ and the mean maximum and minimum temperatures are $34^{\circ} \mathrm{C}$ and $19^{\circ} \mathrm{C}$, respectively (Esayas et al., 2013).

The field experiments were designed in Randomized Complete Clock Design (RCBD) with three replications. There were two treatment sets of experiments: open field and controlled field. The treatments in both experiments were arranged in three weeding regimes: No-weeding, One hand weeding at 20 DACE, Two hand weeding at 34 DACE and Three hand weeding at 48 DACE. For both experiments, the popular cotton variety in Ethiopia, Deltapine-90, was planted by fulfilling all agronomic recommendations necessary for raising a successful crop except application of insecticides. For the assessment of insect pests and weed in experimental field, a fixed quadrant with a dimension of 1 by $1 \mathrm{~m}\left(1 \mathrm{~m}^{2}\right)$ was used. Three such quadrants were randomly placed in each plot of all treatments both for open $=$ and controlled fields. Insect pest's adult were collected from both weeds and cotton plant within placed quadrant twice a week. The adult insects were collected by hand picking and starting from 20 DACE to crop maturity during the early and late hours of the day. To count eggs and nymphs of insects which can't be seen with the necked eyes, hand lens was used. In addition, swept net was used for collecting flying insects. The adult insects both on cotton and weeds in the quadrant were collected and recorded. The insect pests collected were taken to the laboratory, separated, identified and counted in relation to their alternative host weed species. Data on yield and yield components of cotton were collected. The dynamics of insect during the study period was also analyzed. The data were analyzed using SAS statistical analysis package 9.2. Means were separated using the Fisher's Least Significant Difference (LSD).

\section{RESUlT}

\section{Composition of insect species in the study Area}

A total of 14 insect species, belonging to 13 families, and one spider were identified from the experimental fields during study period. From 14 insect species identified, 11 were known cotton pest and 3 were beneficial insects (Table 1). About $50 \%$ of the total insect species were only from order Hemiptera and the rest from Coleoptera, Lepidoptera, Thysanoptera and Neuroptera. This is supported 
by Mesbah et al. (2003) who recorded nine insect species, (seven pests and two predators) on the weed, blader hibiscus, in the cotton field. Comparing the two experimental fields, (Open and Controlled) higher number of insects were recorded from controlled field than open field (Figure 1).

\section{Effect of Weed Removal on Insect Population}

Aphis gossypii Glover (Hemiptera; Aphididae) and Thrips tabaci Linn (Thysonptera; Thripidae) population increased with increased weeding regimes while the population of others (Helicoverpa armigera (Hübner), Podagrica spp. and Bemesia tabaci (Gennadius) decreased with increased weeding regimes. In this study, the prevalence of economically important pest (Helicoverpa armigera (Hübner) was low; this may be due to dry whether condition at early stage of the crop growing season. The key role of rainfall in influencing population dynamics of H. armigera is evident from several studies where higher rainfall early in the growing season of crop greatly influences the population of $H$. armigera buildup (Shimuziand Fujisaki, 2002; Shimuzi et al., 2006; Kurban et al., 2007).

Presence or absence of certain weeds may contribute to or reduce insect infestations in crops (Khaliq et al., 2014), weeds modifies within-crop field microclimate (Edwards and Wratten, 1980 and Norris and Kogan, 2000). Of the total insect population collected in this experiments, only two insect pests (B.tabaci and T. tabaci) constituted $56.7 \%$ and $57.5 \%$ in weedy cheek and one hand weeding while two insect pest species (T. tabaci and A.gossypii) constituted $67 \%$ in the three hand weeding regime in open field. Similarly, three insect pests (B. tabaci, Podagrica spp. and Empoasca spp.) and (A. gossypii, Empoasca spp. and T.tabaci) constituted $59.7 \%$ and $69.3 \%$ in weedy cheek and one hand weeding while only two insect pests (A. gossypii and T. tabaci) made up $71.7 \%$ in three-hand weeding regime in controlled fields. Since insect pests could be categorized according to the degree of damage they cause and frequency of occurrence, A. gossypii and T. tabaci considered as a major polyphagous insect pest of cotton in the study area. Helenius (1991) showed that monophagous insects are more susceptible to crop diversity than polyphagous insects and cautioned the increased risk of crop damage if the dominant herbivore fauna in a given agro-ecosystem is polyphagous. Helenius (1998) came to the conclusion that monophagous insects are much more sensitive to the increased diversity of cultivated plants then polyphagous insects. Additionally, management practices for weeds can affect insects and vice versa (Akinyemijuand Olaifa, 1991).

Weedy check has the highest insect population which accounts for 33.7 and $28.1 \%$ of insect species population both on open and controlled field, respectively. One hand weeding account for 16.6 and $23.9 \%$ in open and controlled field. The second highest insect population was recorded from three hand weeding treatments (28.5 and 25.8\%) in open and controlled field, respectively. The absence or presence of weeds in the cotton field is the main factor to influence (increase/decrees) insect pests' population in these experimental fields. Bendixen and Horn, (1981) reported that presence of weeds (alternative hosts) in the crop field is usually, attracting and allowing the pest to build-up its population on the alternative host before moving to the crop. Conversely, rows of crops interspersed with bare soil have sometimes been shown to be more attractive to flying insects (aphids) than dense stands of vegetation, so weeds in crop fields may also deter alighting (Rhainds et al., 2001; Stapleton and Summers, 2002; Stavinsky et al. 2002; Summers and Stapleton,2002). In other words, chemicals play a more important role in the evolution of specific host-herbivore relations than doe's vision (Stanton 1983).

Weeding frequency affects insect species diversity and population of individual species in the cotton field; hence as weeding increases insect species diversity and individual insect population decreases except A. gossypii and T. tabaci. Mayse, (1983) indicate that weeds influence the diversity and abundance of insect population and associated natural enemies in crop systems. Mayse, 1983 also concluded that, the presence of weeds in crops affects plant density and spacing patterns, factors known to significantly influence insect populations. 
Table1. Relative Prevalence of insect species recorded on cotton field at Werer Agricultural Research Center in 2016

\begin{tabular}{|c|c|c|c|c|c|c|c|c|c|c|c|c|}
\hline \multirow{3}{*}{ No } & \multirow{3}{*}{ Order } & \multirow[b]{3}{*}{ Family } & \multirow[b]{3}{*}{ Scientific Name } & \multicolumn{8}{|c|}{ Insect Prevalence (\%) } & \multirow[b]{3}{*}{$\begin{array}{l}\text { Insect } \\
\text { status }\end{array}$} \\
\hline & & & & \multicolumn{4}{|c|}{ Open field } & \multicolumn{4}{|c|}{ Controlled field } & \\
\hline & & & & A & B & $\mathrm{C}$ & $\mathrm{D}$ & E & $\mathrm{F}$ & G & $\mathrm{H}$ & \\
\hline 1 & Lepidoptera & Noctuidae & Helicoverpa armigera(Hübner) & 6 & 3.4 & 1.3 & 1.6 & 5.8 & 0.7 & 1.1 & 1.3 & ++ \\
\hline 2 & Hemiptera & Cicadellidae & Empoasca spp. & $\begin{array}{l}11 . \\
3\end{array}$ & 18 & $\begin{array}{l}17 . \\
6\end{array}$ & $\begin{array}{l}12 . \\
1\end{array}$ & 15 & 14.9 & 9.7 & $\begin{array}{l}10 . \\
4\end{array}$ & + \\
\hline 3 & Hemiptera & Aphididae & Aphis gossypii (Glover) & 6.4 & $\begin{array}{l}14 . \\
4\end{array}$ & $\begin{array}{l}17 . \\
7\end{array}$ & $\begin{array}{l}11 . \\
6\end{array}$ & $\begin{array}{l}12 . \\
6\end{array}$ & 41.3 & $\begin{array}{l}37 . \\
2\end{array}$ & $\begin{array}{l}40 . \\
5\end{array}$ & ++ \\
\hline 4 & Coleoptera & Chrysomelidae & Podagrica spp. & $\begin{array}{l}15 . \\
9\end{array}$ & 2.8 & 1.5 & 0.9 & $\begin{array}{l}20 . \\
5\end{array}$ & $\begin{array}{l}10 . . \\
7\end{array}$ & 2.2 & 1.6 & + \\
\hline 5 & Hemiptera & Pyrrhocoridae & Dysdercus spp. & 0.3 & 0.2 & 0.4 & 0.4 & 0.3 & 1.1 & 0.2 & 0.2 & + \\
\hline 6 & Hemiptera & $\begin{array}{l}\text { Pseudococcida } \\
\mathrm{e}\end{array}$ & Phenacoccus solenopsis(Tinsley) & 0.2 & 0.1 & - & 0.1 & 0.6 & 0.9 & 0.2 & 0.4 & ++ \\
\hline 7 & Hemiptera & Aleyrodidae & Bemesia tabaci (Gennadius) & $\begin{array}{l}34 . \\
9\end{array}$ & $\begin{array}{l}23 . \\
8\end{array}$ & $\begin{array}{l}17 . \\
6\end{array}$ & 15 & $\begin{array}{l}24 . \\
2\end{array}$ & 10.8 & $\begin{array}{l}11 . \\
9\end{array}$ & $\begin{array}{l}12 . \\
4\end{array}$ & ++ \\
\hline 8 & $\begin{array}{l}\text { Thysanopter } \\
\text { a }\end{array}$ & Thripidae & Thrips tabaci (Linn) & $\begin{array}{l}21 . \\
8\end{array}$ & $\begin{array}{l}33 . \\
7\end{array}$ & $\begin{array}{l}39 . \\
2\end{array}$ & $\begin{array}{l}55 . \\
6\end{array}$ & 6.6 & 13.1 & $\begin{array}{l}32 . \\
6\end{array}$ & $\begin{array}{l}31 . \\
2\end{array}$ & ++ \\
\hline 9 & Lepidoptera & Bucculatricidae & Bucculatrix thurberiella & - & 0.3 & 0.1 & - & - & 0.1 & 0.1 & - & + \\
\hline 10 & Hemiptera & Miridae & $\begin{array}{l}\text { Pseudatomoscelis } \\
\text { seriatus(Reuter) }\end{array}$ & 0.1 & 0.5 & - & - & 0.5 & 0.5 & - & - & + \\
\hline 11 & Hemiptera & Cicadellidae & Amrasca spp. & 0.8 & 0.6 & 0.8 & 0.7 & 9.7 & 1 & 0.2 & 0.3 & + \\
\hline 12 & Neuroptera & Chrysopidae & Chrysoperla carnea (Stephens) & 0.8 & 1.3 & 1.7 & 1.1 & 1.1 & 2.3 & 1.9 & 1.2 & - \\
\hline 13 & Coleoptera & Coccinellidae & Hippodamia spp & 0.7 & 0.5 & 1.1 & 0.3 & 0.6 & 1.3 & 0.8 & 0.3 & - \\
\hline 14 & Coleoptera & Meloidae & Epicauta spp. & 0.4 & - & - & - & 0.5 & - & - & - & + \\
\hline 15 & Araneae & & Spiders & 0.7 & 0.4 & 0.7 & 0.5 & 1.9 & 1 & 1.2 & 0.2 & \\
\hline
\end{tabular}

NB. A= Weedy check, $\mathrm{B}=$ One hand weeding, $\mathrm{C}=$ Two hand weedings, $\mathrm{D}=$ Three hand weeding in open field and $\mathrm{E}=$ Weedy check, $\mathrm{F}=$ One hand weeding, $\mathrm{G}=$ Two hand weeding and $\mathrm{H}=$ Three hand weeding in controlled field, $++=$ Major insect pest, $+=$ Minor insect pest and $-=$ Beneficial insect.

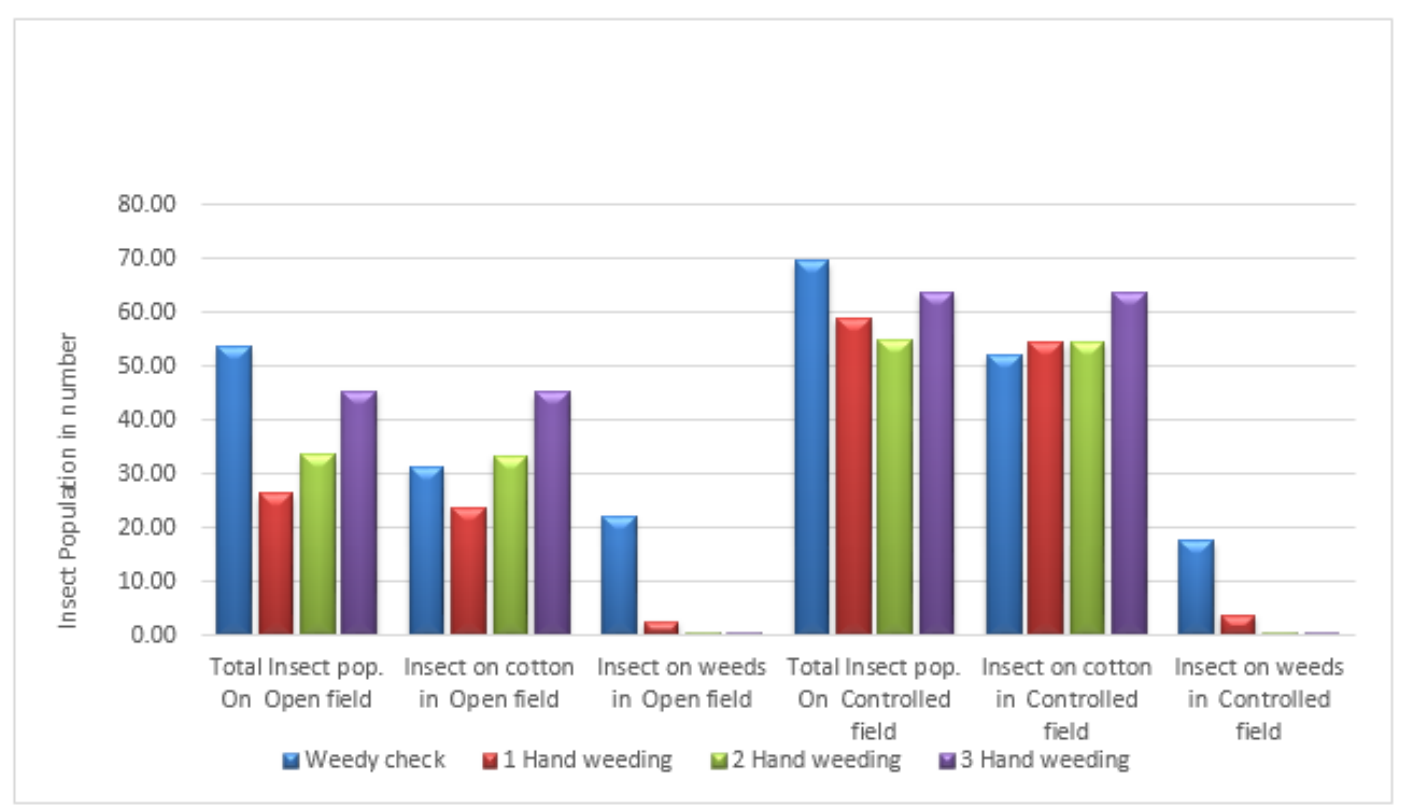

Figure 1. Effect of weeding frequency on insect species population $\left(\mathrm{no} / \mathrm{m}^{2}\right)$

\section{Weed Species that Harbor Insect pests in Cotton Field}

In the cotton field insect pests were recorded from four weed species belonging to four families (Table 2). These were Solanaceae: Datura stramonium L., Tiliaceae: Corchorus trilocularis L., Aizoaceae: Zaleya pentandra L. Jeffrey and Amaranthaceae: Digera muricate (L.) Mart. D.stramonium accounted for harboring $45.27 \%$ and $27.96 \%$ insect species whilst C.trilocularis 
harbored $31.82 \%$ and $62.65 \%$ in open and controlled fields, respectively. The smallest number of insect species was recorded on D. muricata next to Z. pentandra both in open and controlled fields.

The result showed a highly significant difference between weedy checks from which the highest number of insect species were recorded. Increased weeding frequency was also led to decrease in insect population number in both open and controlled fields. The number of insects recorded in weedy check in both open and controlled fields as compared to one hand weeding were $88.7 \%$ and $76.2 \%$ for weedy check and $10 \%$ and $21.6 \%$ for one hand weeding, respectively. The increase in the percentage of insects in one hand weeding under controlled could be attributed to the appearance of C.trilocularis after the first hand weeding but before the second hand weeding in the controlled field. Both two and three hand weeding recorded one and two percent on open and controlled field. From the total insect species recorded per $1 \mathrm{~m}^{2}$ in the field $11.86 \%$ were recorded on weed species namely $D$. stramonium, C. trilocularis, Z.pentandra and D. muricata. Dhanalakshmi et al 2016 reported that Datura ferox, Lantana camera, Nicandra physaloides Abutilon spp., Sida spp., Urena lobata, Chorchorus sp, Hibiscus spp. and pandurae formis are serving as an alternate host for American bollworm, Spotted bollworm boll worm and Pink bollworm in cotton field

\begin{tabular}{|c|c|c|c|c|}
\hline \multirow[b]{2}{*}{ Weed Removal Treatments } & D. stramonium & C. trilocularis & Z. pentandra & D. muricata \\
\hline & \multicolumn{4}{|l|}{ Open field } \\
\hline Weedy check & $3.48 \mathrm{a}$ & $1.51 \mathrm{a}$ & $1.2 \mathrm{a}$ & $0.24 \mathrm{a}$ \\
\hline One hand Weeding at 20 DACE & $0.32 \mathrm{~b}$ & $0.147 \mathrm{a}$ & $0.32 \mathrm{ab}$ & $0.074 \mathrm{ab}$ \\
\hline Two hand weeding at 34 DACE & $0.001 \mathrm{~b}$ & $0.03 \mathrm{a}$ & $0.025 \mathrm{~b}$ & $0.001 \mathrm{~b}$ \\
\hline Three hand weeding at 48 DACE & $0.001 \mathrm{~b}$ & $0.0267 \mathrm{a}$ & $0.013 \mathrm{~b}$ & $0.001 \mathrm{~b}$ \\
\hline C.V & 23.75 & 33.89 & 32.68 & 36.87 \\
\hline S. D & 1.18 & 0.913 & 0.56 & 0.11 \\
\hline \multirow[t]{2}{*}{ LSD (0.05) } & 2.35 & 1.82 & 1.11 & 0.22 \\
\hline & \multicolumn{4}{|l|}{ Controlled field } \\
\hline Weedy check & $1.95 \mathrm{a}$ & $3.376 \mathrm{a}$ & $0.95 \mathrm{a}$ & $0.25 \mathrm{a}$ \\
\hline One hand Weeding at 20 DACE & $0.13 \mathrm{~b}$ & $1.37 \mathrm{ab}$ & $0.12 \mathrm{a}$ & $0.045 \mathrm{a}$ \\
\hline Two hand weeding at 34 DACE & $0.04 \mathrm{~b}$ & $0.078 \mathrm{~b}$ & $0.034 \mathrm{a}$ & $0.038 \mathrm{a}$ \\
\hline Three hand weeding at $48 \mathrm{DACE}$ & $0.02 \mathrm{~b}$ & $0.07 \mathrm{~b}$ & $0.001 \mathrm{a}$ & $0.0003 \mathrm{a}$ \\
\hline C.V & 23.61 & 35.79 & 32.08 & 34.56 \\
\hline S. D & 0.5 & 1.29 & 0.52 & 0.19 \\
\hline LSD (0.05) & 1.01 & 2.58 & 1.05 & 0.38 \\
\hline
\end{tabular}

$\underline{\text { NB }} . \mathrm{CV}=$ Coefficient of variation, $\mathrm{SD}=$ Standard deviation $\mathrm{LSD}=$ Least significance difference at $(\mathrm{P} \leq 0.05)$ the mean values with different letters represent significant variation and the mean values with the same letters are not significantly different

\section{Effect of Weed Removal on Yield and Yield Component of Cotton}

Different yield attributes, such as number of bolls per square meter and ball weight were affected by weed removal (Table 3). Weedy cheek has lower number of balls, plant population and ball weight. The yield components except plant height were increased as the weed-free period increased and showed decreasing trend as the weed infestation period increased from 20 DACE onwards. Velayutham et al., (2002) and Srinivasan (2003) reported that un-weeded check reduced the boll number per plant and boll weight of cotton. Mohamed and Bhanumurthy (1985) reported significant reduction in fruiting points due to uncontrolled weed growth in the field.

Weed removal treatments resulted in significantly higher plant height, a greater number of open bolls, higher boll weight, and leaf area index and seed cotton yield than weedy check. Weed removal might have resulted in optimum utilization of environmental resources by the crop which enhanced the yield components and finally seed cotton yield. These results are also supported by other findings elsewhere Douti, (1997), Sadras (1997) and Lamm et al., (2002).

\begin{tabular}{|c|c|c|c|c|c|c|c|}
\hline Weed Removal Treatments & Yield & NoB & H.ball & Un. OB & $\mathrm{PP}$ & $\mathrm{PH}$ & BW \\
\hline & \multicolumn{7}{|c|}{ Open field } \\
\hline
\end{tabular}




\begin{tabular}{|l|l|l|l|l|l|l|l|}
\hline Weedy check & $4.568 \mathrm{c}$ & $3.517 \mathrm{c}$ & $3.039 \mathrm{~d}$ & $1.731 \mathrm{c}$ & $3.557 \mathrm{~b}$ & $114.490 \mathrm{a}$ & $1.698 \mathrm{~b}$ \\
\hline One hand Weeding at 20 DACE & $18.104 \mathrm{~b}$ & $6.416 \mathrm{~b}$ & $5.024 \mathrm{c}$ & $3.869 \mathrm{~b}$ & $4.220 \mathrm{ab}$ & $61.730 \mathrm{c}$ & $2.264 \mathrm{~b}$ \\
\hline Two hand weeding at 34 DACE & $23.079 \mathrm{a}$ & $7.812 \mathrm{a}$ & $6.124 \mathrm{~b}$ & $4.821 \mathrm{ab}$ & $4.667 \mathrm{a}$ & $82.110 \mathrm{bc}$ & $3.018 \mathrm{a}$ \\
\hline Three hand weeding at 48 DACE & $24.281 \mathrm{a}$ & $8.873 \mathrm{a}$ & $6.812 \mathrm{a}$ & $5.647 \mathrm{a}$ & $4.890 \mathrm{a}$ & $107.780 \mathrm{ab}$ & $3.204 \mathrm{a}$ \\
\hline C.V. $(\%)$ & 13.822 & 8.462 & 4.115 & 18.094 & 11.763 & 14.589 & 12.954 \\
\hline S. D & 2.42 & 0.563 & 0.216 & 0.727 & 0.51 & 13.353 & 0.33 \\
\hline LSD $(0.05)$ & 4.835 & 1.125 & 0.432 & 1.452 & 1.018 & 26.678 & 0.659 \\
\hline & \multicolumn{7}{|l|}{ Controlled field } \\
\hline Weedy check & $4.783 \mathrm{c}$ & $4.414 \mathrm{~b}$ & $3.919 \mathrm{~b}$ & $2.020 \mathrm{~b}$ & $4.000 \mathrm{~b}$ & $135.067 \mathrm{a}$ & $1.659 \mathrm{~b}$ \\
\hline One hand Weeding at 20 DACE & $17.376 \mathrm{~b}$ & $7.331 \mathrm{a}$ & $5.894 \mathrm{a}$ & $4.736 \mathrm{a}$ & $4.113 \mathrm{~b}$ & $107.867 \mathrm{~b}$ & $1.983 \mathrm{~b}$ \\
\hline Two hand weeding at 34 DACE & $22.244 \mathrm{a}$ & $9.022 \mathrm{a}$ & $6.863 \mathrm{a}$ & $5.850 \mathrm{a}$ & $5.000 \mathrm{a}$ & $107.000 \mathrm{~b}$ & $3.071 \mathrm{a}$ \\
\hline Three hand weeding at 48 DACE & $22.861 \mathrm{a}$ & $8.422 \mathrm{a}$ & $6.655 \mathrm{a}$ & $5.161 \mathrm{a}$ & $5.000 \mathrm{a}$ & $116.933 \mathrm{ab}$ & $3.070 \mathrm{a}$ \\
\hline C.V. $(\%)$ & 13.666 & 11.647 & 10.478 & 19.661 & 2.167 & 9.658 & 27.407 \\
\hline S. D & 2.298 & 0.85 & 0.611 & 0.873 & 0.098 & 11.272 & 0.67 \\
\hline LSD $(0.05)$ & 4.592 & 1.698 & 1.221 & 1.745 & 0.196 & 22.52 & 1.339 \\
\hline
\end{tabular}

$\underline{\text { NB }} . \mathrm{NoB}=$ Number of ball, H.ball $=$ harvested ball, UnOP. $=$ Number of unopened balls, PP $=$ Plant Population, $\mathrm{PH}=$ Plant height, $\mathrm{BW}=$ Ball weight, $\mathrm{CV}=$ Coefficient of variation, $\mathrm{SD}=\mathrm{Standard}$ deviation, $\mathrm{LSD}=$ Least significance difference at $(\mathrm{P} \leq 0.05)$, the mean values with different letters represent significant variation and the mean values with the same letters are not significantly different.

\section{CONClusion}

Weedy check recorded a diverse and high population of insect species than one and two hand weeding while three hand weeding has less diverse and high population of polyphagous insect species. This revealed that, presence of diverse plant species in agroecology, insects have chance of selecting favorable host in feeding and oviposition and thus maintain their higher population. The insect pest encountered in this study appeared in two categories in relation to the weed situation in the cotton agroecosystem. As weeding regime increases in the cotton field diversity of insect pests' decreases and the population of polyphagous insects (Aphis gossypii and Thrips tabaci) increases. This clearly indicates, presence of weeds can enhance or hinder insect fitness within the cotton field through modification of micro-climate. This is probably due to the fact that, weeds provide much of the canopy early or late in the crop growing season providing conducive situation for early and late coming insects, respectively. Weeds within the crop field can also modify the attractiveness of insects to the crops by affecting the hue (color) and odor of the crop field which needs further justification by studying response of insects to color of plants and odor they emit.

\section{RECOMMENDATION}

For effective insect pest management in cotton, growers should concentrate their efforts on weed management at early time of the growing season. Weeding two times at 20 and 34 DACE results in better cotton yield and yield components. Thus, to boost the yield of their crop, cotton growers should align weeding time to these schedules. In general, this study showed the need of appropriate weed management, which is resulted in high crop yield through reduction of weed competition and minimization of insect pest damage by denying alternative host

\section{REFERENCES}

[1] Akinyemiju, O.A., Olaifa, J.A. (1991) Relative Importance of Weeds and Insect Pest Control in Cowpea Production In: Cowpea production. Nigerian J of Weed Sci. 4:43-53

[2] Andow, D.A (1983) Effect of agricultural diversity on insect populations. In: Lockeretz W., (ed.) Environmentally sound agriculture, Praeger, New York, 91-115 PP.

[3] Basset, Y., Cizek, L. and Cuénoud, P. (2012) Arthropod diversity in a tropical forest: Science, 338, 14811484.

[4] Bendixen, L.E. and Horn, D.J. (1981) An Annotated Bibliography of Weeds as Reservoirs of Organisms Affecting Crops. Ohio Res. \& Dev Centre, Wooster, 117 PP. 
[5] Capinera, J.L. (2005) Relationships between insect pests and weeds: An evolutionary perspective. Weed Science, 53(6): 892-901.

[6] Douti, P.Y. (1997). Cotton crops versus weeds: when is the competition period? Agric. Dev.11-16 PP.

[7] Dhanalakshmi Ramachandra, G. Ramamohan, Ashish Bhan and P.J. Suresh (2016) Weed management in cotton: The potential of GM crops Indian Journal of Weed Science 48(2): 136-143

[8] Edwards P.J. and Wratten, S.D. (1980) Ecology of Insect-Plant Interactions. London: Arnold. 60 PP.

[9] Esayas T., Abraham G.H. and Mashila D. (2013) Ethiopian Journal Applied Science Technology 4: 41-49.

[10] Gliessman, S.R. (2001) Agroecology: the ecology of sustainable systems, using weed borders to manage insect pests in California cauliflower fields. Second Edition, $282 \mathrm{PP}$.

[11] Helenius, J. (1991) Insect numbers and pest damage in intercrops vs. monocrops: Concepts and evidence from a system of faba bean, oats and Rhopalosiphumpadi (Homoptera, Aphididae). Journal of Sustainable Agriculture, 1: 57-80.

[12] Helenius, J. (1998) Enhancement of predation through within-field diversification. In Pickett, C.H. \&Bugg, R.L. (Eds.), Enhancing Biological Control: habitat management to promote natural enemies of agricultural pests. Berkeley: University of California Press, 121-160 PP.

[13] Hillocks, R.J. (1998) The potential benefit of weeds with reference to small holder agriculture in Africa. Integrated pest management reviews. 3:155-167.

[14] Kennedy, G.G. (1993) Impact of intraspecific variation on insect pest management. In: Kim, K.C. and Mcpheron, B.A. (Eds.), Evolution of Insect Pests: Pattern of Variation. Wiley: New York, 425-451 PP.

[15] Khaliq, A., Javed, M., Sohail, M. and Muhammad, S. (2014) Environmental effects on insects and their population dynamics. Department of Agricultural Entomology, University of Agriculture, Faisalabad, Pakistan Journal of Entomology and Zoology Studies, 2 (2): 1-7

[16] Kostal, V. and Finch, S. (1996) Preference of the cabbage root fly, Delia radicum (L.), for colored traps: influence of sex and physiological status of the flies, trap background and experimental design. Physiol. Entomol. 21:123-130.

[17] Kurban, A.,Yoshida, H,. Izumi, Y., Sonoda, S. and Tsumuki, H. (2007) Pupal diapause of Helicoverpa armigera (Lepidoptera: Noctuidae): Sensitive stage for thermal induction in the Okayama (western Japan) population. Bull. Entomol.Res., 97: 219-223.

[18] Lamm, R. D, Slaughter, D.C. and Giles, D.K. (2002) Precision weed control system for cotton. Transact. ASAE 45: 231-238.

[19] Mayse, M. A. (1983) Cultural control in crop fields: A habitat management technique. Environmental Entomology 7: 15-22.

[20] Mesbah, A.H., Boraei, H.M. and El-Heneidy, A.H. (2003) Importance of Hibiscus trionum L. weed, as a source of insect pests infesting cotton plants at Kafr El-Sheikh Governorate. Egypt. J. Agric. Res., 81(4): 1609-1618.

[21] Mohamed, Ali A. and Bhanumurthy, V.B. (1985) Trianthema portulacastrum L. under irrigated conditions. Trop. Pest Mgt., 31(3): 232-234

[22] Norris, R.F. and Kogan, M. (2000) Interactions between weeds, arthropod pests and their natural enemies in managed ecosystems. Weed Sci. 48:94-158

[23] Norris, R.F. (1982) Interactions between weeds and other pests in the agroecosystem. In: Hatfield, J.L. and Thomason, I.J., (eds.) Biometeorology in integrated pest management, Academic Press, New York PP 343406.

[24] Nyambo, B.T. (1988) Significance of host-plant phenology in the dynamics and pest incidence of the cotton bollworm, Heliothis armigera (Lepidoptera:Noctuidae) in western Tanzania. Crop Prot. 7: 161-7.

[25] Nyambo, B.T. (1990) Effect of natural enemies on the cotton bollworm Heliothis armigera (Lepidoptera: Noctuidae) in western Tanzania. Tropical Pest Management 36:50-8.

[26] Ochoa Martinez, D.L., Zavaleta, Mejia, E.,Mora Aguilera, G. and Johansen, N.R.M. (1999) Implications of weed composition and thrips species for the epidemiology of tomato spotted wilt in chrysanthemum (Dendranthema grandiflora). Plant Pathol.48:707-17

[27] Rhainds, M., Kovach, J., Dosa, E.L. and English-Loeb, G. (2001) Impact of reflective mulch on yield of strawberry plants and incidence of damage by tarnished plant bug (Heteroptera: Miridae). J. Econ. Entomol. 94:1477-1484.

[28] Sadras, V.O. (1997) Effects of simulated insect damage and weed interference on cotton growth and reproduction. Anna. Appl. Biol. 130: 271-281.

[29] Shimuzi, K. and Fujisaki, K. (2002) Sexual differences in diapause induction of the cotton bollworm, Helicoverpa armigera (Hb.) (Lepidoptera: Noctuidae). Appl. Entomol. Zool., 37: 527-533. 
[30] Shimuzi, K., Shimizu, K. and Fujisaki, K. 2006. Timing of diapause induction and overwintering success in the cotton bollworm Helicoverpa armigera (Hb.) (Lepidoptera: Noctuidae) under outdoor conditions in temperate Japan. Appl. Entomol. Zool., 41: 151-159.

[31] Srinivasan, G. (2003) Boi-efficacy of prometryn for weed control in summer irrigated cotton. Madras Agric. J., 90 (4-6): 243-246.

[32] Stanton, M. L. (1983) Spatial patterns in the plant community and their effects upon insect search. In: Ahmad, S. (ed.) Herbivorous insects: Host-seeking behavior and mechanisms. New York: Academic, 125 $157 \mathrm{PP}$

[33] Stapleton, J. J. and Summers, C. G. (2002) Reflective mulches for management of aphids and aphid-borne virus diseases in late-season cantaloupe (Cucumis melo L. var. cantalupensis). Crop Prot. 21:891-898.

[34] Stavinsky, J., Funderburk, J., Brodbeck, B.V., Olson, S.M. and Andersen, P.C. (2002) Population dynamics of Frankliniella spp. and tomato spotted wilt incidence as influenced by cultural management tactics in tomato. J. Econ. Entomol. 95:1216-1221.

[35] Summers, C. G. and Stapleton,J. J.(2002) Use of UV reflective mulch to delay the colonization and reduce the severity of Bemisia argentifolii (Homoptera: Aleyrodidae) infestations in cucurbits. Biol. Control, 21: 921-928.

[36] Thresh, J. M. (1981) Pests, pathogens and vegetation: The role of weeds and wild plants in the ecology of crop pests and diseases. Pitman, Boston, $531 \mathrm{PP}$.

[37] Van Emden, H. F. and Dabrowski, Z.T. (1997) Issues of biodiversity in pest management. Insect Science and Applications, 15: 605-620.

[38] Velayutham, A., Ali, A.M. and Veerabadran, V. (2002) Influence of intercropping systems and weed management practices on the growth and yield of irrigated cotton. Madras Agric. J., 89 (1-3): 59-62.

[39] William, R. D. (1981) Complementary interactions between weeds, weed control practices, and pests in horticultural cropping systems. Hort Science, 16: 508-513.

[40] Wilson, L.J. (1995) Habitats of two spotted spider mites (Acari: Tetranychidae) during winter and spring in a cotton producing region of Australia. Environ.Entomol.24:332-40

Citation: Workishet Taye " Effect of Weed Management on Insect Pest Population on Cotton (Gossypium Hirsutum L.) At Werer, Ethiopia." International Journal of Research Studies in Agricultural Sciences (IJRSAS), 2021; 7(1), pp. 24-31, https://doi.org/10.20431/2454-6224.0701003

Copyright: () 2021 Authors. This is an open-access article distributed under the terms of the Creative Commons Attribution License, which permits unrestricted use, distribution, and reproduction in any medium, provided the original author and source are credited. 